\title{
Palladium-Catalyzed Cross-Coupling of Triorganoindium Reagents
}

indium

palladium

imidazoles<smiles>Ic1nc(I)n(Cc2ccccc2)c1I</smiles>

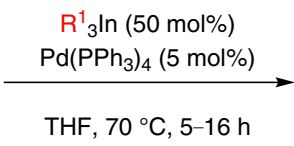

$\mathrm{R}^{1}=\mathrm{R}^{2}=\mathrm{Ar}$, HetAr, alkynyl<smiles>Ic1nc(I)n(Cc2ccccc2)c1I</smiles>

up to $84 \%$ yield

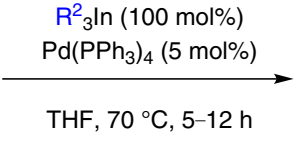<smiles>[R]c1nc([R])n(Cc2ccccc2)c1[R]</smiles>

up to $98 \%$ yield

Selected examples:<smiles>Fc1ccc(-c2nc(I)c(I)n2Cc2ccccc2)cc1</smiles>

$83 \%$ yield<smiles>COc1ccc(-c2nc(I)c(I)n2Cc2ccccc2)cc1</smiles>

$78 \%$ yield<smiles>Ic1nc(-c2ccco2)n(Cc2ccccc2)c1I</smiles>

$83 \%$ yield<smiles>Fc1ccc(-c2nc(-c3cc4ccccc4s3)c(-c3cc4ccccc4s3)n2Cc2ccccc2)cc1</smiles><smiles>COc1ccc(-c2nc(-c3ccco3)n(Cc3ccccc3)c2-c2ccccc2)cc1</smiles>

$90 \%$ yield

Significance: The authors demonstrate that triorganoindium reagents react selectively with $N$-benzyl-2,4,5-triiodoimidazole under palladium catalysis to give the corresponding C-2-arylated coupling products in good yields. These products can further be used in a subsequent double cross-coupling to afford trisubstituted imidazoles in good yields.
Comment: This methodology was further applied to the synthesis of neurodazine, a biologically active compound which is able to specifically induce neurogenesis of non-pluripotent myoblasts and the cells derived from mature human skeletal muscle. 